Georgetown University Institutional Repository http://www.library.georgetown.edu/digitalgeorgetown

The author made this article openly available online. Please tell us how this access affects you. Your story matters.

OSGOOD, J. "Nuptiae lure Civili Congruae: Apuleius's Story of Cupid and Psyche and the Roman Law of Marriage" Transactions of the American Philological Association (1974-), Vol. 136, No. 2 (Autumn, 2006), pp. 415-441

Collection Permanent Link: http://hdl.handle.net/10822/555440

(C) 2006 The John Hopkins University Press

This material is made available online with the permission of the author, and in accordance with publisher policies. No further reproduction or distribution of this copy is permitted by electronic transmission or any other means. 


\section{Nuptiae Iure Civili Congruae: Apuleius's Story of Cupid and Psyche and the Roman Law of Marriage}

\section{JOSIAH OSGOOD}

Georgetown University

SUMmary: Social historians, despite showing great interest in Apuleius's Metamorphoses, have tended to ignore the novel's embedded tale of Cupid and Psyche on the grounds that it is purely imaginary. This paper demonstrates that Apuleius in fact refers throughout his story to real Roman practices, especially legal practices-most conspicuous are the frequent references to the Roman law of marriage. A careful examination of several passages thus shows how knowledge of Roman law, it turns out, enhances the reader's pleasure in Apuleius's story. The paper concludes by exploring the connections between Apuleius's fairytale and the account of his own marriage to Aemilia Pudentilla in his earlier work, the Apologia. Apuleius seems to be recalling, playfully, his own earlier legal success. At the same time, both works suggest that legal problems arose in Roman families not because of the actions of any official enforcers, but rather appeal to the law by particular family members.

IN AN IMPortant PAPER, "THE WORLD of the golden ass," Fergus Millar suggests that Apuleius's Metamorphoses takes place in "an invented world of fiction" but also represents "features of the real world" (75). In three situations these realia are especially engaging for the social historian: when the novel portrays "areas of social life which ancient literature usually passes over"; when it adds "color to patterns which we already know from other, more formal evidence"; and when it offers "alternative models of society to those which we normally accept" (66). Apuleius's insertions into the Greek story he used as a source are particularly relevant for the scholar trying to see this real Roman world. ${ }^{1}$ But, Millar argues, the longest interpolation, the

${ }^{1}$ That these insertions, not found in the pseudo-Lucianic epitome, are original to Apuleius himself cannot be doubted; Mason gives a full discussion. Of course, a Greek novel could include references to contemporary Roman institutions: see Schwartz and the earlier studies she cites. 
story of Cupid and Psyche, told by a nameless old woman to comfort the captive Charite, proves a notable exception, since unlike the other additions, "it is set in an imaginary time and place" (65). Erant in quadam civitate rex et regina...: this is the beginning of a fairytale, which connects the tale to the world of other fantastic stories. ${ }^{2}$

And yet, I will argue, a closer look reveals that, despite its imaginary subject matter, Apuleius's story of Cupid and Psyche does refer to real Roman practices. Often these "Roman" practices are longstanding customs of Roman citizens that originated in Italy; occasionally they are more peculiar to those living under Roman rule (but perhaps not actually citizens) in one or more of the provinces; or they may be practices shared by both. ${ }^{3}$ As with the Metamorphoses as a whole, the field of reference is the complex world of the sprawling Roman empire of the second century C.E., where provincials adapted traditional Roman customs (even before becoming citizens), and where citizens might retain customs different from those of old Rome. In this world, boundaries between provincial and Roman, or provincial and Italian, were lessening, which is partly why nostalgia for what appeared to be a simpler Rome-or Greece-of long ago is not uncommon in imperial literature. Yet, we should remember, despite the mingling of different customs, it was sometimes challenging to combine local ways with Roman citizenship and the ius civile that came with it.

Apuleius - a native of north Africa and a citizen of Rome, a Latin writer and a Greek sophist (as well as, almost certainly, a speaker of Punic), a visitor to parts of the empire east and west-was very much a part of this world, and his works, including the story of Cupid and Psyche, are an important witness to it. ${ }^{4}$ Yet in referring to Roman institutions in his novel, ${ }^{5}$ Apuleius did not aim to offer a source to today's social historians. Rather, as Andrew

${ }^{2}$ Laird 149-50.

${ }^{3}$ Assessing the "Roman-ness" (or Romanitas) of provincial societies in the Roman empire has become a priority in social historical scholarship. Discussions of the "Romanness" of the family-one preoccupation of this essay-in the provinces can be found, for instance, in Bradley 2000a and 2000c (both based on Apuleius) and in the essays of George. One recent and fascinating discussion of the "Roman-ness" of legal practice-another preoccupation of this essay-in the provinces is given by Meyer 169-215. An especially suggestive set of evidence, that brings the concerns of family and law together, is the recently discovered archive of Babatha, an inhabitant of the province of Arabia who, though not a citizen, had some familiarity with Roman law: for one discussion, see Cotton.

${ }^{4}$ For one especially good discussion of this, see Bradley 2000a: 296-303.

5 "Roman" here refers to the broad sense of the word discussed above, i.e., "of Roman citizens and of those under Roman rule." 
Laird suggests, he was helping his audience to connect with the tale. ${ }^{6}$ (These references also make the story relevant, at least at times, to its listener Charite, whose own marriage, interrupted by bandits who seized her, has parallels to Psyche's. ${ }^{7}$ ) Apuleius's readers may recognize similarities between their world and the novel's, or perceive a gap, often humorous, between them.

Who were these readers? Many of them must not have been unlike Apuleius - westerners, for the most part, since the language is Latin, and ideally familiar with much of Latin literature that came before (else his language can be hard to understand). Having made this intellectual investment, they are likely to have been of means, and to have been citizens, and therefore conversant with Roman law. The effort to educate themselves perhaps brought them to different parts of the empire, as it did Apuleius and his fellow student and roommate in Athens, Sicinius Pontianus, who hailed from Oea, in Tripolitania. They were, then, a highly privileged audience. ${ }^{8}$

Assuming that Apuleius's mention of Roman practices does link his fairytale to the world of these readers, modern scholars can try to read in reverse, as it were, to see what is taken as familiar. We will hardly gain documentary evidence for social history, but may be able to see how distinctive institutions of Roman society were thought of (thus adding "color to patterns" known from other evidence) and we may even glimpse "alternative models." We also gain insight into the social and intellectual horizons of Apuleius's audience. The sorts of questions that engaged Roman jurists, it will emerge, are not irrelevant to the story.

To take just one example: as Venus prepares to travel to Olympus to visit Mercury, "she ordered her chariot to be prepared, which Vulcan the goldsmith had carefully finished with the most refined craftsmanship and given to her as a wedding gift before her first experience of the marriage bed; it was beautiful from the rubbing of the polishing file and costly because of the forfeiture of the gold itself" (iubet construi currum quem ei Vulcanus aurifex subtili fab-

${ }^{6}$ Laird esp. 151. Bradley 2000a: 291 independently makes a similar point.

${ }^{7}$ This aspect of the story of Cupid and Psyche is discussed, by, e.g., Winkler 50-6 and Papaioannou - though the latter is misleading on legal matters. I do not consider this or other narratological features of the tale.

${ }^{8}$ Older views about the readership of the Metamorphoses (and the ancient novel more generally) have been changing. The idea (anachronistic, I believe) that it was addressed to some kind of "middle class" has been challenged. Two discussions, with earlier references, are given by Stephens and Dowden. (I do not support, however, Dowden's early dating of the novel). Harrison 2002 and Graverini discuss the implications of the novel's settings, while Finkelpearl 134-44 argues that Apuleius's network of allusions to Dido in the tale of Charite may imply a Carthaginian audience. See also Bradley 2000a: 296-301. 
rica studiose poliverat et ante thalami rudimentum nuptiale munus obtulerat limae tenuantis detrimento conspicuum et ipsius auri damno pretiosum, 6.6). ${ }^{9}$ Apuleius has to create a means of conveyance appropriate to the haughty deity-and, to prepare for the scene on Olympus, seeks to shift his story into an epic register-so he looks to the Homeric vehicle of the gods, a chariot. ${ }^{10}$ More specifically, the author has in mind Ovid's dazzling description of the chariot of Helios, a passage he alters, though, as if to suggest the refinement of his own car-and remind us that we are not reading an epic. ${ }^{11}$ Like the novel's numerous other intertexts, these epic models are crucial to appreciating this passage; yet to them, Apuleius adds a very real, contemporary detail. ${ }^{12} \mathrm{He}$ imagines the chariot to be the present that Roman grooms sometimes gave their brides-generally before their wedding, if they were Roman citizens, since gifts between married couples were prohibited by the law, in order to keep husband and wife's property separate. ${ }^{13}$

These gifts might be tokens of esteem; they also might be a reward, sometimes substantial, given to the bride for her virginity—a highly valued quality, as, for instance, epitaphs show. ${ }^{14}$ Though such gifts, at least in more elaborate form, were a practice that originated in provincial society rather than in Italy, they became more widely known over time in the cosmopolitan empire, and so a part of what "Roman" marriage could be. ${ }^{15}$ Juvenal refers to the custom casually in his notorious satire on the subject $(6.200-05):{ }^{16}$

${ }^{9}$ I have used the text printed by Kenney. Translations are mostly my own, but occasionally borrow a phrase from Kenney. See also the recent editions of Moreschini; and Zimmerman, Panayotakis, et al., the latter exceptionally valuable.

${ }^{10}$ This and most of the following point are discussed in detail by Zimmerman, Panayotakis, et al. ad loc.

${ }^{11}$ Ov. Met. 2.105-10, with remarkable emphasis on the gold in lines 107-8: aureus axis erat, temo aureus, aurea summae / curvatura rotae.

${ }^{12}$ Finkelpearl is a sensitive study of Apuleius's art of allusion, and reviews earlier views on the subject.

${ }^{13}$ Unless their marriage was with manus. (The law recognized certain other exceptions, e.g., spouses could give in contemplation of divorce-see Dig. 24.1.11.11-12 [Ulpian and Paul], 24.1.60 [Hermogenian]). Brides might also give their grooms gifts. On prenuptial donations, see Corbett 205-10, Anné 239-471, Treggiari 1991: 152-3, 165-6, Evans Grubbs 1995: 156-83, Arjava 52-62. These last two studies splendidly reveal the importance of late antique evidence for the study of classical law.

${ }^{14}$ On the bride's virginity see, e.g., Treggiari 1991: 105-7, 315-16, Evans Grubbs 1995: 195, Arjava 220. On epitaphs, see Lattimore 278.

${ }^{15}$ See especially Evans Grubbs 1995: 181.

${ }^{16}$ Recognized by Anné 303 n. 1 (who also cites the Apuleius passage) and Courtney ad loc. 
si tibi legitimis pactam iunctamque tabellis

non es amaturus, ducendi nulla videtur

causa, nec est quare cenam et mustacea perdas

labente officio crudis donanda, nec illud

quod prima pro nocte datur, cum lance beata

DACICVS et scripto radiat GERMANICVS auro.

If you're not going to love the woman who was betrothed to you and joined by legal contract, there seems no reason to marry. There's no point in wasting the meal and cakes that have to be given to the bilious guests as the gathering is breaking up, and the money that is given for the first night, when 'VICTOR IN DACIA' and 'VICTOR IN GERMANY', inscribed in gold, gleam on a rich platter.

Both novelist and satirist describe a similar gift: gold objects (a chariot, in one case, coins and a platter, in the other), delivered to the bride at the time of her marriage, in recognition of her first sexual experience. Apuleius corroborates Juvenal's claim that a sum in gold was a price a man might pay for marriage, especially to a virgin. The novelist cannot tell us how frequent such a practice was, but, like Juvenal, suggests its familiarity. At the same time, when we recognize the custom described, we share the delight of Apuleius's readers, who would have found the idea of Venus receiving a gift that apparently rewarded her virginity most amusing.

The classical legal sources, as they come down to us, though familiar with gifts between betrothed couples, do not describe this sort of present as such; later, in a law of 321 , Constantine would refer to it as a praemium pudicitiae. ${ }^{17}$ Yet we may have a reference to it in the second century jurist Scaevola, who begins discussion of a scenario of just the sort he relished as follows: "A virgin was led to the estate [of her husband] two days before the marriage took place and she lived in a chamber separate from him. On the day of marriage, before she crossed to him...that is, before the marriage was celebrated, he provided her ten pieces of gold as a gift" (Virgini in hortos deductae ante diem tertium quam ibi nuptiae fierent, cum in separata diaeta ab eo esset, die nuptiarum, priusquam ad eum transiret [...] id est nuptiae celebrentur, optulit decem aureos dono, Dig. 24.1.66.1). ${ }^{18}$ As in Juvenal and Apuleius, a virgin (or a woman putatively a virgin) is presented with a gift of gold at the time of her wedding by her husband.

But whether Scaevola is thinking of such a gift or not, the rest of his opinion is relevant to the question of Venus's nuptiale munus. Having sketched in

${ }^{17}$ Cod. Theod. 9.42.1 = Cod. Iust. 5.16.24.

${ }^{18}$ Translations of the Digest are based on those in the edition of Watson. 
the background, he then raises the question: "If a divorce took place after the marriage was contracted, could the sum that was given be reclaimed?" (post nuptias contractas divortio facto an summa donata repeti possit, 24.1.66.1). That is, could the gift be deducted-along with, for instance, a sum to defray the cost of raising children-from the amount of dowry that the husband returned? The jurist replied: "what was stated as having been given before the marriage could not be deducted from the dowry" (id, quod ante nuptias donatum proponeretur, non posse de dote deduci).

The question of when the marriage took place is the crucial one here: if the gift had been given after the marriage began (which was not necessarily the time of the wedding ${ }^{19}$ ), it was illegal, ${ }^{20}$ and so could be recovered from the wife by deducting it from her dowry. Thus, while a reward for virginity would naturally be given after the wedding night, in Roman law it could not. That is, a groom observing the law gave it before marriage, and could never afterwards recover it. One can easily see why, over time, as prenuptial gifts proliferated, a more detailed law concerning them would arise. The key point for our purposes is that the gift a married woman received from her fiancé was hers to keep: this sheds light on Juvenal's caution about such presents, and also, it would seem, Apuleius's description of the precious chariot. Since Venus and her fellow deities, as we shall see, have already by this point in the story been shown acting as if they were citizens of Rome, the phrase ante thalami rudimentum nuptiale munus effectively underscores for an audience familiar with Roman law the gift's value and links the world of the fairytale to that in which they lived. For us, it provides insight into how such gifts were viewed, thereby adding "color" to a pattern already known.

The world of Cupid and Psyche, then, does share something with the world of the Golden Ass when it alludes to Roman institutions. While earlier scholarship identified many of these references, it was less concerned to show how, cumulatively, they invite the reader to think of the union in Roman terms; ${ }^{21}$

${ }^{19}$ The transfer of the girl to her fiancés house could be seen as the start of marriage, since living together signified the consent that was the basis of marriage in classical law; no other wedding ceremony was legally required. As Modestinus writes: "Living with a free woman ought to be understood as marriage, not concubinage, provided she does not make money out of prostitution" (In liberae mulieris consuetudine non concubinatus, sed nuptiae intellegendae sunt, si non corpore quaestum fecerit, Dig. 23.2.24).

${ }^{20}$ Unless it was given in contemplation of divorce.

${ }^{21}$ But cf. Summers 1970: 518 n. 20, describing the festival of Laughter in the third book of the Metamorphoses: "The technically correct usage of a large number of Roman legal and quasi-legal terms [...] should be noted here as ancillary evidence that Apuleius wanted the reader to comprehend the scene in terms of Roman law." On Roman references in the Metamorphoses, see above all Norden, who will not be cited in what follows, 
one of these references, Jupiter's announcement that the couple has a marriage "in accord with the civil law" is especially important, since the question of the marriage's legality, in particular, becomes crucial. These studies paid less attention to the implications this issue has concerning Apuleius's audience and instead sought to demonstrate that Apuleius himself had legal training-a conclusion no doubt true but somewhat beside the point. ${ }^{22}$

In the rest of this article, then, I do not offer a literary analysis of the fairytale, but rather identify references to Roman practices (especially legal practices) and show that they are used in a way consistent with each other-and, on the whole, with evidence from other sources; throughout, I explore what resonance such references might have had for Apuleius's first readers. I do so to show that Apuleius's fairytale has a double significance for social historians: it sheds light on distinctive features of Roman institutions, especially marriage (but also, e.g., slavery), and how they struck the imagination; it also speaks to the outlook of Apuleius's second-century audience, for whom a key part of being — or becoming — "Roman" was a familiarity with the prescriptions of Roman law. In making these arguments, I add to the work of Millar and also several engaging papers on the novel by Keith Bradley. ${ }^{23}$ In the final section, I suggest that, while the allusions to law may not have a clear literary purpose, they do remind the reader of another marriage described in Apuleius's writings: his own. I will explain why that might be so, and in doing so shall return to the question of Apuleius's audience.

\section{NUPTIAE CONFARREATAE: PSYCHE'S USE OF LEGAL LANGUAGE}

Several clear references to Roman institutions occur midway through the tale when Psyche launches her unexpected plan for revenge on her sisters, and offer a good point of departure. After telling the nameless pair how her lamp spilled a drop of hot oil and awakened Cupid, she then imagines him to have said: "You, for this very wicked crime of yours, be divorced from my bed immediately and have your own things. I, however, will take as my

though he comments on many passages that concern me. He organized his material juristically (e.g., "Sklaven und Halbfrei" and "Eherecht"), rather than by its appearance in the novel. See also Summers 1970 and 1972, Quartuccio, Elster, Maehler, and Keulen. Since this paper is primarily concerned with the law of marriage, I do not discuss, e.g., the iustitium mentioned at Met. 4.33.

${ }^{22}$ The latter observation is made by Keulen 203-4.

${ }^{23}$ Bradley 2000a and 2000b. Other uses of creative literature by social historians include Hopkins and Saller 1993, the latter a study of Roman comedy to "indicate... possible Roman scenarios." 
wife your sister (and he said the very name by which you are registered) in a confarreatio marriage" ("tu quidem [...] ob istud tam dirum facinus confestim toro meo divorte tibique res tuas habeto, ego vero sororem tuam"- et nomen quo tu censeris aiebat- “iam mihi confarreatis nuptiis coniugabo" 5.26). The distraught girl uses here, in addition to the already clear expression toro meo divorte, a legally binding formula for divorce that went back well into the Roman republic. Further, after pointing to one of her sisters (we do not know which one), she says that Cupid wishes to remarry, and the marriage will be one in which the sister passes into the manus (i.e., control) of her husband by the ancient rite of confarreatio. It was more difficult to end a marriage of this sort: but who, Psyche implicitly is pointing out, would divorce a god? Earlier in the story, we should note, there has been no sign that Psyche's own union is conceived in these terms. While Psyche's odd funeral-wedding displayed features of the traditional Roman (i.e., Italian) wedding, it was not a ceremony of confarreatio. ${ }^{24}$

The key to understanding Psyche's use of legal language lies in comparing her version of what happened in Cupid's palace with what the narrator tells us. After the oil awakened him, the old woman says, the god left the bed and scolded Psyche, ending his remarks by saying, "just by taking flight I will have punished you" (te vero tantum fuga mea punivero, 5.24). Here, the situation is much more ambiguous: has Cupid divorced his wife? To make her plan effective, Psyche needs to suggest more emphatically that a divorce took place. Thus (in addition to claiming that Cupid said toro meo divorte) she uses the ancient divorce formula of Roman citizens. Of this formula, the jurist Gaius, a contemporary of Apuleius, writes, "With repudiation, that is, renunciation, these words are accepted: 'Have your own things' or 'Look after your own things"' (In repudiis autem, id est renuntiatione comprobata sunt haec verba: "tuas res tibi habeto," item haec: "tuas res tibi agito" Dig. 24.2.2.1). The expression was not mandatory, according to Gaius, but when invoked, it could end a marriage.

One may suspect that, though Gaius mentions the formula, it was not a typical procedure in the Roman empire of the second century C.E. ${ }^{25}$ Apuleius's passage certainly does not supply evidence that it was. Still, the fairytale sheds some light on how divorce was perceived. In a marriage in which the bride did

${ }^{24}$ The wedding is described at Met.4.33-5. Psyche, for instance, sports the flammeum, the flame-colored wedding veil; cf. Treggiari 1991: 163. She also has a deductio in domum mariti (or pompa-a term Apuleius uses), with the appropriate torchlight, piping, and wedding hymn; cf. Treggiari 1991: 166.

${ }^{25}$ Treggiari 1991: 447; on Roman divorce, see Corbett 218-48, Treggiari 1991: 435-82, Evans Grubbs 1995: 225-60, Arjava 177-89. 
not pass into her husband's manus (already by the late Republic the norm), divorce was not a formal ceremony (as it was in marriage with manus) and need not involve written documents. ${ }^{26}$ Rather, when one party no longer felt good will toward the other, he or she could notify the spouse (by a messenger, for instance), reclaim his or her property, and then be considered divorced. This, of course, could take time-and it meant that if a husband or wife simply left in anger, a divorce had not necessarily occurred. Paul, for instance, writes: "There is not a true divorce unless it is made with an intention to remain apart permanently. So things said or done in anger are not confirmed until by its persistence it was clear that a considered judgment was made" (Divortium non est nisi verum, quod animo perpetuam constituendi dissensionem fit. itaque quidquid in calore iracundiae vel fit vel dicitur, non prius ratum est, quam si perseverantia apparuit iudicium animi fuisse, Dig. 24.2.3, partially repeated at 50.17.48). ${ }^{27}$ Invoking the divorce formula may not have been enough (though it could, after the fact, be deemed the end of a marriage). That someone besides a jurist might view this situation as ambiguous is suggested by Psyche's mention that Cupid announced his plan to remarry, for, as Treggiari 1991: 450 notes, "valid marriage to someone else confirmed divorce from a former partner." Though the claim that Cupid sought one of her sisters is necessary to Psyche's plan, it also reinforces her account of a Roman divorce.

Apuleius's invocation of the divorce formula, as mentioned, cannot show that it was actually used-much less, frequently-in his day; indeed, it does not effect a divorce in the story itself. Rather, as with other uses of it in Latin literature, it serves as an emphatic statement rather than a performative utterance. ${ }^{28}$ Yet if Psyche's speech does not attest a practice common among Apuleius's readers, it may suggest their interest in the ancient customs of Roman citizens (as attested in an author such as Plautus). ${ }^{29}$ The divorce formula

${ }^{26}$ The very specific procedure referred to by Paul (Dig. 24.2.9) is generally taken to have been necessary only in the case of divorcing an adulterous wife.

${ }^{27}$ Cf. Dig. 23.2.33 (Marcellus), 24.2.7 (Papinian).

${ }^{28}$ E.g., Plaut. Trin. 268, Cic. Phil. 2.69, Sen. Suas. 1.6. Rosenmeyer 206 gives a sensitive discussion of Plautus's deployment of the divorce formula, pointing out that, "[i]f the words constitute their own realization in non-fictional experience, Plautus must make sure that the words will not be allowed to fulfill themselves." Apuleius may have Psyche vary the normal order of the phrase (tuas res tibi habeto) for similar reasons.

${ }^{29}$ In addition to Plaut. Trin. 268, see Amph. 928. Antiquarians would also be delighted, for instance, by the out-of-date technical expression loca lautia praebere (meaning "to furnish hospitality to distinguished foreign visitors at state expense") at Met. 3.26. On Apuleius's archaizing (and the archaizing of his age more generally) see, e.g., Marache, Callebat, Mattiaci, and Sandy 49-60. 
may be almost as much a fossil in Gaius's commentary as in Apuleius, yet this may be part of its appeal to both authors.

One can argue so because the same is true of Psyche's mention of a marriage with manus. Such a marriage for a woman normally had two related disadvantages: she passed into her husband's control, even if sui iuris herself, and her property became his. Further, once undertaken, divorce was a complex process (as pointed out above) and therefore less frequent. For these reasons, in part, it had fallen out of favor by the late Republic, though in the imperial period occupants of certain patrician priesthoods, for instance, had to marry with confarreatio. ${ }^{30}$ The idea of a marriage with manus, then, had a special resonance, as the writings of Gaius again suggest: his elementary legal textbook, which deems the subject worthy of several chapters (1.108-14), discusses in some detail one way of entering manus that the author admits was obsolete by his day. Apuleius's appeal to it suggests the resonance too. It is perhaps not entirely fanciful to imagine that an upwardly mobile Gaul or African, whose family may have recently gained citizenship, could be intrigued by the ancient Roman custom, lovingly described by antiquarians, and occasionally observed by those with certain pretensions.

\section{NUPTIAE IMPARES: VENUS'S APPEALS TO THE LAW}

Psyche' fictitious divorce raises the question of what sort of union she has with Cupid, a question of real importance in the rest of the story. This starts to become clear when, after Cupid's desertion, word finally reaches Venus of her son's doings and the goddess asks her colleagues to help in finding Psyche. "But I beg you," Venus says, "with all your strength find Psyche for me, that elusive runaway" (sed totis, oro, vestris viribus Psychen illam fugitivam volaticam mihi requirite, 5.31). To the goddess, who feels she owns Psyche, that girl is now a fugitiva, a runaway slave. The other immortals accept this identification, as Juno's refusal to help the girl makes clear: "Then there is also the fact that I am prohibited by the laws which forbid taking in other people's runaways against their master's wishes" (tunc etiam legibus quae servos alienos profugos invitis dominis vetant suscipi prohibeor, 6.4).

Juno refers here to a very real point in Roman law: namely, as Ulpian says, Is qui fugitivum celavit fur est (Dig. 11.4.1.1). This was true in Italy. It was also true in the provinces, as an imperial constitution roughly contemporary with Apuleius's novel shows: "There is also a general letter of the deified Marcus

${ }^{30}$ Though its legal effects were limited: the evidence is Tac. Ann. 4.16 and Gai. Inst. 1.136, discussed by Treggiari 1991: 23 and 30-1, which also gives other evidence to suggest that marriage with manus had not ceased altogether. 
and Commodus in which it is announced that governors, magistrates, and soldiers on police duty must assist the owner in searching for runaways: they are both to return them when they find them and to punish the people on whose property they hide, if an offense is involved" (est etiam generalis epistula divorum Marci et Commodi, qua declaratur et praesides et magistratus et milites stationarios dominum adiuvare debere inquirendis fugitivis, et ut inventos redderent, et ut hi, apud quos delitescant, puniantur, si crimine contingantur, Dig. 11.4.1.2). ${ }^{31}$ Bowersock has argued that the novel must refer to, and therefore postdate, this letter..$^{32}$ If so, Juno's apology humorously reflects a sudden, real worry of provincial life; for previously, a provincial owner received far less official help in the recovery of his slaves, and those who hid runaways- whether citizens or not-therefore had less to fear from the relevant authorities. Yet even if the reference is more general, it still would be amusing for Apuleius's readers to imagine a goddess limiting her actions out of respect for Roman law-even as they try to determine whether Psyche is actually a slave.

Yet while officials might help in Italy and, later, the provinces, Venus's behavior conforms far better to the traditional attitude of "taking the matter into one's own hands," and for this reason Bowersock's dating remains uncertain. ${ }^{33}$ She decides on a public announcement (by Mercury, of course) advertising the fugitive's features and a reward that she herself will furnish for return of the property. "There's nothing left," she orders, "but to announce publicly with your proclamation a search reward. See to it that you carry out my order quickly and clearly specify the features by which she can be recognized" (nil ergo superest quam tuo praeconio praemium investigationis publicitus edicere. fac ergo mandatum matures meum et indicia qui possit agnosci manifeste designes, 6.7). She then hands over a handbill (libellum) containing Psyche's name and the other details (Psychen nomen...et cetera). The procedure is in accordance with Roman law. Ulpian remarks: "To the magistrate should be reported the name and distinguishing features of the runaways (the term 'distinguishing features' also includes scars), and those to whom they say they belong, so that they can more easily be recognized and caught" (Eorumque nomina et notae et cuius se quis esse dicat ad magistratus deferantur, ut facilius adgnosci et percipi fugitivi possint (notae autem verbo etiam cicatrices continentur), Dig. 11.4.1.8a). ${ }^{34}$ But he then immediately adds: "The law is the same if you

${ }^{31}$ On fugitivi see Bellen, with discussion of the role of Roman officials at 9-16. Praesides implies a provincial setting: cf. Dig. 11.4.3 (Ulpian), which cites a rescript of Antoninus Pius, a first step toward Marcus's more expansive law.

${ }^{32}$ Bowersock 282 n. 31.

${ }^{33}$ See especially Summers 1973.

34 "Wanted notices" that survive on papyri illustrates what notae are; see, e.g., P.Oxy. 3616-17. 
post this information up in public notices or on a temple" (idem iuris est, si haec in scriptis publice vel in aedes proponas). Venus basically has chosen this second path, and so illustrates for Apuleius's readers her effort to take charge of the situation.

Mercury issues his edict as follows (6.8):

si quis a fuga retrahere vel occultam demonstrare poterit fugitivam regis filiam, Veneris ancillam, nomine Psychen, conveniat retro metas Murtias Mercurium praedicatorem, accepturus indicivae nomine ab ipsa Venere septem savia suavia et unum blandientis adpulsu linguae longe mellitum.

If anyone can stop from flight or show where the runaway princess is hidden, the handmaid of Venus, who goes by 'Psyche,' let him report to Mercury, this announcer, behind the Murcian turning posts. He will receive as reward for his information seven sweet kisses from Venus herself and one extra, deeply honeyed by the application of her sweet tongue.

Apuleius surely has in mind here a clever poem of Moschus, in which Aphrodite announces a reward for a different runaway, her son Eros. His variation on it underscores the novelty of his story. Yet as with the goddess's chariot, the author has also added contemporary Roman details. He alters Moschus's language to bring the announcement into line with a form known through epigraphic and papyrological examples, from Italy and the provinces, concerning other missing property. A hand-written notice from Pompeii, for instance, announces the reward for returning a vase: Vrna aenia pereit de taberna. Seiquis rettulerit, dabuntur HS LXV... (CIL 4.64). And another notice from the town specifies whom to contact and where: if someone finds a horse, convenito Q. Deciu $\{m\}$, Q. l(ibertum) Hilarum...citra pontem Sarni fundo Mamiano (CIL 4.3864). Collars worn by slaves also sometimes gave an "address" for returning a runaway: "the barber's quarters near the Temple of Flora," for instance, or "in the Forum of Trajan at the Portico of Porphyry" (ad Flora ad tosores and in foro Traiani in Purpuretica, CIL 15.7172 and 7191). Thus, the seven kisses plus one and the precise phrase conveniat retro metas Murtias Mercurium praedicatorem conform-flippantly-to a social reality (though Mercury does forget to give Psyche's notae).

There is humor in Apuleius's portrayal of Venus, the goddess-cumslaveholder who jealously guards her possessions, or what she claims to be her possessions; but it also reveals that such legal self-help must have been familiar to Apuleius's readers, even as, like other creative literature, it makes the form of self-help even more familiar. ${ }^{35}$ It was a part of life, one can as- 
sume, throughout the second century empire. By contrast, the reference to the shrine of the goddess Murcia (in the Circus Maximus in Rome), a place where prostitutes were said to gather, would appeal to inhabitants of that city, or those familiar with it-that is, Apuleius's cosmopolitan audience of Romans, Italians, and western provincials. ${ }^{36}$

The proclamation contains the juxtaposition fugitivam regis filiam, a phrase that highlights the delightful absurdity of Psyche's status as slave. In the fictional tale, however, it seems plausible that she, as mortal, can play that role to Venus's (and Cupid's) godhead. But if Psyche is of servile status, and Venus and Juno are acting as cives Romani, then a reasonable objection to her marriage can be made, as any reader-citizen or not-would almost instinctively know; and, we will see, Venus is just the person to do so. A citizen could not legally marry a slave: cum servis nullum est conubium (Tit. Ulp. 5.5). Nonetheless, it was possible to manumit a slave and then marry her, a practice attested in many inscriptions. Viro et patróno placui et décessi prior, Julia Erotis is made to say in her epitaph, to quote just one (CIL 6.5254). Perhaps, then, Cupid could claim that he had freed Psyche. A certain amount of prejudice, however, was attached to such matches, and, in part for this reason, Augustus in his marriage legislation prevented the Senatorial class from marrying freedpersons.

Even though we are reading a fairytale, this prejudice is exemplified for us in a list of complaints Venus makes about her son's marriage: "it is... an unequal match and furthermore took place in the country, without witnesses, and without the father's consent it cannot be considered valid" (impares [...] nuptiae et praeterea in villa sine testibus et patre non consentiente factae legitimae non possunt videri, 6.9). If the pregnant Psyche bears a son, the goddess continues, the child will be illegitimate, using the legal term spurius. ${ }^{37}$ Despite her rage, there is a clear progression in Venus's outburst here. She begins by complaining that the marriage is impares-not legal terminology (as, for instance, spurius is) but an expression for a match between two people of different status. ${ }^{38}$ Venus could simply mean that Cupid is divine, Psyche is mortal, and their child, therefore, will be mortal. But since she has emphasized again and again that she views Psyche as a slave, there seems also to be a more Roman-sounding complaint about Psyche's social status. Venus sounds something like Tacitus's absurdly haughty Julia, who scorned marriage with Tiberius as if he were an impar (Ann. 1.53).

${ }^{36}$ See Graverini 70-1, Harrison 2002: 49-50, Rosati 280.

${ }^{37}$ On the term spurius and its various meanings, see Rawson 1989: 14-15.

${ }^{38}$ See Treggiari 1991: 85 n. 14, and also Zimmerman, Panayotakis, et al. ad loc. The phrase matrimonium impar can also imply a disparity of age. 
With et praeterea Venus introduces two complaints that she views as more serious, and which more unambiguously refer to Roman institutions. She first suggests that the marriage was a fly-by-night affair. Such an undesirable match, it had to take place in the countryside and lacked the witnesses who often appeared to sign a marriage contract at a Roman wedding. ${ }^{39}$ This contract, which might only concern the dowry, was not legally required for marriage, and therefore not an essential ceremony. In a union without manus, as virtually all modern scholars agree, consent of the bride and groom (and those in whose power they lay) alone was the basis for marriage (just as considered withdrawal of consent was the basis for divorce). ${ }^{40}$ Though the jurists, as passed down to us, lack full discussion, various of their opinions help make this clear. Sexual intercourse was not required, as Ulpian says: "Sleeping together does not make a marriage but consent does" (Nuptias...non concubitus, sed consensus faciat, Dig. $35.1 .15=50.17 .30)$. Nor was a contract, according to Ulpian's teacher Papinian: "It is not documents that make a marriage" (neque enim tabulas facere matrimonium, Dig. 39.5.31.pr.). But Venus's complaint suggests that, whatever the jurists might say, for some Romans-citizens and provincials-it was the contract, the witnesses, or a public ceremony that made the marriage. Indeed, Papinian's denial suggests this too. The novel, then, hints at an alternative model of marriage, perhaps also implied by Juvenal's phrase legitimis pactam iunctamque tabellis quoted above. ${ }^{41}$

Venus's final objection is potentially more damning than the first two, because it invokes an indisputable point of law. She points out that Cupid's father (name unspecified) did not provide his consent to the marriage. For this reason, a reader thinking in terms of Roman law could consider it illegitimate: as Paul says, "Marriage is not able to come into existence unless everyone consents, that is, those who join together, and those in whose power they are" (nuptiae consistere non possunt nisi consentiant omnes, id est qui coeunt quorumque in potestate sunt, Dig. 23.2.2). Without iustum matrimonium, there could not be legitimate offspring either-hence the child will be a spurius, his mother's only, not part of Cupid's familia. ${ }^{42}$ For Apuleius's

${ }^{39}$ Zimmerman, Panayotakis, et al. ad loc. suggest that Venus is complaining that the marriage is not by confarreatio, which required ten witnesses. But the phrase in villa suggests that it is more the lack of any public ceremony that bothers her.

${ }^{40}$ See Treggiari 1991: 170-80, citing some of the earlier literature, including Corbett. Volterra is a crucial study too.

${ }^{41}$ Likewise the euphemism at Met. 5.4 (uxorem sibi Psychen fecerat) suggests that one could see sexual intercourse as a necessary part of becoming married.

${ }^{42}$ Some jurists might not use spurius in the sense Venus does (since the term was defined variously), but nevertheless it is not necessary to insist, with Keulen 218, that a Greek notion of illegitimacy underlies Venus's complaints. Venus appeals to Roman law-whether correctly or not is the question Apuleius poses. 
audience, these references to Roman law would, like those concerning fugitivi, be humorous-not least because Cupid's father was a notorious subject of debate. ${ }^{43}$ Yet they would also be puzzling. Is Psyche to be considered a slave, Cupid a citizen of Rome? Is, then, Venus's objection legally valid? Her only other reference to Cupid's father is similarly vague (5.29). And what of the odd marriage of Psyche described near the start of the story? Could that itself be deemed legitimate? Did the oddness of her wedding — not actually a requirement for marriage-matter?

While the conundrums are typical of a novel in which it is hard to tell appearance from reality, we note that it is a character in the story who precipitates the problem. As with Psyche and her sisters, the use of legal language gives Venus's speech a certain efficacy; it is an effort to sound powerful, even menacing. Yet it underscores, for the modern scholar, the very real fact that the mother had no power, legally speaking, over her child's marriage, even in the father's absence. ${ }^{44}$ All the same, appeal to the law itself was a strategy one might use in a familial dispute-a point to which we shall return.

Venus's arguments prompt an additional reflection. While, as stated, the uncertainty surrounding Cupid and Psyche's marriage is patently part of this author's notorious elusiveness, to a contemporary reader, especially of provincial origin, the question of whether Roman law applied (and if so, how) may well have resonated. As provincials became citizens, they struggled to learn the law and determine the extent to which it was reconcilable with local customs. Yet even when not citizens, and so not subject to the ius civile, they had to make guesses about what their Roman rulers would and would not accept, and the intelligent guess considered what the law had to say. In the early second century C.E., to cite only one instance, the Jewish (or almost certainly Jewish) woman Babatha, an inhabitant of the new province of Arabia but not a Roman citizen, tried to use rules of Roman civil law to remove the guardians of her son and gain control of his property. ${ }^{45}$ Roman law governed citizens' lives and could have clear consequences for the individual; yet we

${ }^{43}$ As Kenney notes ad loc. But while he notes "contemporary legalism" in Venus's complaint, Kenney is wrong to say that "if Cupid was indeed ingenuus et investis [5.28], this was a real objection." The objection stood as long as a Roman son was in potestate; his age was irrelevant. (Ceres and Juno's remarks at Met. 5.31 strongly suggest that, in any case, Venus was wrong to claim that Cupid was still investis - that is, an impubes, under the age of fourteen.) Likewise, while Keulen 215 is right to emphasize that Venus's arguments reflect a Roman mentality, it is not true that "equal marriage" as such was "an important principle of Roman law."

${ }^{44}$ Evans Grubbs 2005: 118-20 has a good discussion of several rescripts which show mothers trying to dissolve their daughters' marriages.

${ }^{45}$ See Cotton. 
should not overlook the influence it could have even on those not formally subject to it. Apuleius's incorporation of references to the ius civile into his fabula Graecanica, in which few characters are Roman citizens, parallels Roman law's intrusion into the provinces, not least when the references seem most jarring. ${ }^{46}$

\section{NUPTIAE IURE CIVILI CONGRUAE: JUPITER'S LEGAL RULING}

While Venus's claim that Cupid and Psyche have an "unequal" marriage does not rely on legal phraseology, as the story progresses, it emerges that it may in fact have legal significance. This is because in Apuleius's imaginary world, the gods, as often in Latin literature, are depicted as members of the Senatorial nobility. The idea goes back to Lucilius, who parodied the epic concilium deorum by having his Olympians (all males, appropriately) follow the procedure of the Roman Senate. ${ }^{47}$ Seneca exploits the device in Apocolocyntosis, and there are hints of it in some famous passages of Latin epic that would have been especially familiar to readers of the Metamorphoses, not least in Ovid's poem of the same name. Thus, at the end of his fairytale, Apuleius describes Zeus calling a meeting of the divine Senate (6.23):

sic fatus iubet Mercurium deos omnes ad contionem protinus convocare, ac si qui coetu caelestium defuisset, in poenam decem milium nummum conventum iri pronuntiare. quo metu statim completo caelesti theatro pro sede sublimi sedens procerus Iuppiter sic enuntiat: 'dei conscripti Musarum albo...'

Thus he spoke and ordered Mercury to call all of the gods straightaway to assembly, and to announce that if any one were missing from the divine gathering, a penalty of ten thousand sesterces would be assessed. Because of this threat, the heavenly theater was filled immediately. Tall Jupiter, sitting on his raised throne, thus spoke: 'Conscript gods, registered in the role call of the Muses...'

The parody could not be clearer: the Senator-gods, humorously called dei conscripti, face a fine for non-attendance, known in Republican times, increased and enforced more vigorously under Augustus. ${ }^{48}$ And their names are inscribed not on the album senatorium but an album Musarum..$^{49}$ Apuleius

${ }^{46}$ Rosati offers stimulating remarks on Apuleius's "Romanization" of the novel.

${ }^{47}$ See the fragments of book 1 with commentary in Charpin. But the germ of the idea may already have been in Ennius: see esp. fr. 52 Skutsch with the commentary ad loc.

${ }^{48}$ Dio 55.3: the measures referred to here are generally taken to be the lex...de senatu habendo which Gellius (NA 4.10.1) says was in effect in his time. See Talbert 138-9 and 221-4.

${ }^{49}$ See Talbert 17. As Zimmerman, Panayotakis, et al. note ad loc., both contio and provoco are used elsewhere in referring to meetings of the Senate. 
adds a more provincial touch, though, when he imagines the meeting at a theater: in the Greek east, assemblies could take place in such venues. But specific parody aside, it was natural enough for a Roman to think of the gods as corresponding to those of highest status-the Senatorial order.

An additional problem, then, one can envision facing Psyche the fugitiva and Cupid, of Senatorial stock, is that, as mentioned above, Augustus's lex Iulia forbade marriage between Senators and former slaves. The Digest, happily, records the relevant portion of the law: "Let no man who is or will be a Senator, or a Senator's son, or a grandson from a son, or a great-grandson from a grandson born to a son, knowingly and intentionally takes as his betrothed or his wife a freedwoman" " $Q$ ui senator est quive filius neposve ex filio proneposve ex $<$ nepote $>$ filio nato cuius eorum est erit, ne quis eorum sponsam uxoremve sciens dolo malo habeto libertinam" 23.2.44.pr.). ${ }^{50}$ By this provision, a Senator could not even manumit a slave and marry her since she would be a freedwoman. Should they do so, the marriage, until the law became stricter under Marcus Aurelius, would not be considered null, but lacked privileges accorded to those of married status. ${ }^{51}$ Venus's phrase impares nuptiae therefore may be seen in retrospect as concealing a legal objection too, one as serious as the lack of Cupid's father's consent.

And yet, as is appropriate for a fairytale, its teller will—almost magically-dispatch both objections to achieve the required happily-ever-after (in this case, a matrimonium iustum). What is particularly wonderful, though, is that the problems have a legal solution. How? The answer comes when Cupid realizes that he must petition Jupiter for help: Iovi supplicat suamque causam probat (6.22). Jupiter, here, is naturally seen as the divine-stand in for the princeps, ${ }^{52}$ and so supplicare can bear its technical sense of presenting the emperor with a request for a decision in a legal matter.

It is at this point that the emperor calls the Senate (in the passage quoted above) for a dramatic speech, full of surprises, in front of a large audience. Jupiter announces that Cupid has sown enough wild oats and must be made respectable by a steady marriage. For too long he has defied, and defiled, the laws, including, Jupiter says explicitly, the lex Iulia concerning adultery. The

${ }^{50}$ For a recent overview of the Augustan marriage legislation, see McGinn 70-84.

${ }^{51}$ The key text here turns out to be Dig. 23.2.16.pr (Paul). Astolfi 109-14 gives a clear discussion.

${ }^{52}$ Apuleius already likened the king of gods to the king of men in the episode where Lucius unsuccessfully tried to cry out "O Caesar" to petition the emperor. Though Caesar could not hear the supplication, he miraculously answered Lucius's prayers by having (unwittingly) compelled the villagers to festoon their houses (along his processional route) with garlands of roses. Lucius describes the answering of his prayers thus: Sed tandem mihi inopinatam salutem Iuppiter ille tribuit (3.29). 
god will have no more of it, and like an emperor, will force his relation ${ }^{53}$ to marry-just as Augustus made Tiberius wed Julia, even though Tiberius was not yet at the time under Augustus's potestas. He thus overrides Venus's objection concerning lack of the father's consent.

As emperor, duly petitioned, Jupiter can take care of the couple's other problem too. As he explains to Venus, parodying Vergil: "Daughter do not be sad at all, nor fear for your issue or your status because of this mortal marriage. Now I will make this not an unequal match, but one legal and in accord with the civil law" (nec tu [...] filia, quicquam contristere nec prosapiae tantae tuae statuque de matrimonio mortali metuas. iam faxo nuptias non impares sed legitimas et iure civili congruas, 6.23). Venus need not worry about the lex Iulia that here prohibits marriage between mortals and gods. By a wave of the wand (or rather, by offering a sip of ambrosia), Jupiter will change Psyche's status: sume, Psyche, et immortalis esto: "Take this, Psyche, and be immortal!"

A wonderful fairy-tale ending, appropriate for a novel of metamorphosesand yet, one conceivable in real life too. It is of great interest to read Ulpian's comment, from his lengthy work on the Augustan marriage laws: "If a Senator is given permission by the kindness of the emperor to have a freedwoman as his fully lawful wife, she can be his fully lawful wife" (Si senatori indulgentia principis fuerit permissum libertinam iustam uxorem habere, potest iusta uxor esse, Dig. 23.2.31). As emperor, Jupiter can solve Cupid's legal problems with just a few words. So the real emperor, with just a few words, could allow a Senator in love with a slave to marry her. Apuleius relies on this fact to help achieve a definitive ending to his story. His contemporaries, in Rome, Italy, and the provinces, were well familiar with the idea that some disputes were so intractable that a solution had to be sought from the princeps, since what he said could not be contested. Jupiter's use of legal language, then, differs in this important respect from Venus and Psyche's. It is not merely emphatic, but definitive, not legalistic, but law itself. It provides, too, an important confirmation for the reader that legal issues were at stake earlier in the story, and it helps to make clearer what those issues were-even though the notion that the Olympians live by Roman law will never lose all of its strangeness.

While Jupiter's ruling, then, serves to bring closure to the fairytale, for social historians, reading in reverse, it gives evidence of how an institution of Roman society could strike the imagination. For Apuleius, and for his readers, the indulgentia of the emperor might very well seem to be almost a

${ }^{53}$ Jupiter claims that he brought up Venus's child at Met. 6.23: adolescentem istum... manibus alumantus sim. Alumni were children reared, but generally not adopted, by a foster parent; see Rawson 1986. Venus also claims to have brought up Cupid, apparently in the absence of his birth father: see Met. 5.29. 
divine power. We can read in our legal sources countless responses, rescripta (or, more properly, subscriptiones) of emperors to various citizens, of varying status: some grant petitions, others deny them, but exceptions to existing laws are very rare indeed. ${ }^{54}$ But if we can read the responses, we can only imagine what a successful answer meant to a petitioner. Apuleius's story gives insight. A special dispensation from the emperor, granting whatever it did, could, for some Romans, have seemed the stuff of fairytales. The phrase immortalis esto! has almost the same resonance as faxo nuptias... legitimas et iure civili congruas.

A response to Charite's own story, the tale of Cupid and Psyche is also a story of marriage, from its odd beginnings to its happy ending: "Thus Psyche with due observance passed into the manus of Cupid and when her term came a daughter was born to them whom we call Pleasure" (sic rite Psyche convenit in manum Cupidinis et nascitur illis maturo partu filia, quam Voluptatem nominamus, 6.24). As in New Comedy, or the Greek novel, a marriage helps bring the story to an end. Yet to this, as we have come to expect, Apuleius adds a Roman touch. Cupid and Psyche's earlier union has been turned into a totally proper and highly traditional marriage with manus, a form peculiar to Roman citizens. This passage again suggests the special resonance that institution had. And in addition to the marriage, there will be offspring-and the offspring, as Jupiter's ruling made clear, will be legitimate.

So, in the end, Cupid and Psyche live and love in accord with ius civile. Apuleius's readers can take pleasure not only in the story's traditional ending, but the details of Roman society that have been incorporated into it, some known from their day-to-day existence, others more from their reading. He has linked the world of the story to theirs, not so much by reproducing the latter in the former, but by a set of rather teasing references. For us, he has shown something about how certain Roman institutions were perceived, and suggested something about the tastes of his audience: we cannot, of course, in the end truly know what his audience knew, but the fact remains that even today someone with an interest in Roman law derives an extra delight in the story that the uninitiated will not. The same is true of someone familiar with the contents of Apuleius's Apologia, which gives an account of the author's own, rather unusual marriage.

${ }^{54}$ On rescripts see esp. Honoré. Evans Grubbs 2005 puts some of them to good use to discuss conflict in the Roman family. 


\section{NUPTIAE IN VILLA: APULEIUS'S ARGUMENTS ABOUT THE LAW}

Men and women living in the second-century empire cohabited with great variety. Although a citizen's ability to marry (conubium) was defined exactly in Roman law, there were other ways to live together, none of which was thought to be sinful as such. A citizen could, for instance, have a marriage recognized by civil law but in violation of a specific decree (e.g., the lex Iulia de maritandis ordinibus). This, as we saw, at least for a time entailed legal penalties but did not render the act totally invalid. Were there a more significant legal disqualification or a considered lack of consent, then concubinage rather than marriage might exist. But this relationship, judging from epigraphic evidence, could resemble marriage. The same is true of contubernium, the relationship in which at least one partner was a slave. ${ }^{55}$ Marriage to a non-Roman might occur too, but was considered legitimate only in special circumstances; Gaius, concerned about the status of the children from such unions, has a long discussion of this point (Inst. 1.65-96).

Provincials, too, had their own marriage customs which might persist into the empire. In North Africa, for instance, it has been argued, a traditional form of remarriage, in which a widow married her late husband's brother, survived into imperial times-and in fact, Apuleius's Apologia supplies some of the evidence. ${ }^{56}$ This practice was not forbidden by Roman law (until a law of Constantius II in 355 C.E.), which meant that those who had Roman citizenship-like the protagonists of the Apologia-could continue to practice it if they wished. ${ }^{57}$ But other customs, such as brother-sister marriage, or bigamy, could not be recognized when Roman citizenship was acquired.

Therefore, while men and women could cohabit in a variety of ways, for citizens old and new establishing that one was in a marriage "legitimate and in accordance with the civil law" did matter when questions of property distribution, legitimacy, and status arose, and it also mattered because of the penalties and rewards created by Augustus's laws on marriage. Thus, because of the flexibility in social arrangements, and the lack of requirements concerning the marriage ceremony itself, a couple often chose to draft-and have witnessed-a marriage contract; otherwise, their relationship might be

${ }^{55}$ On concubinage and contubernium see Treggiari 1991: 51-4, Evans Grubbs 1995: 261-316, Arjava 205-18.

${ }^{56}$ See most recently Corbier 2005: 269-71, who also cites CIL 8.8937.

${ }^{57}$ The law is Cod. Theod. 3.12.2. It was confirmed by later legislation. 
interpreted in different ways. ${ }^{58}$ This, as we saw, was part of the problem Cupid and Psyche faced in their marriage.

Herein lies the parallel with Apuleius's marriage to the rich widow Aemilia Pudentilla. Assuming, as is generally believed, that the Apologia predates the Metamorphoses, one might think that Venus's accusations in the novel owe something to those that Apuleius claims were made against him. ${ }^{59} \mathrm{At}$ his trial, we are told, Apuleius was faulted because of the vast gulf between Pudentilla's wealth and status and the philosopher-rhetorician's. For such a well-off woman, marriage to the relatively poor, and stereotypically mendicant, sophist made the man look like a fortune-hunter. Only the use of magic could explain her choice. Furthermore, because the match was so unequal, and hence scandalous, it was a hushed-up affair: "in a farmhouse and not in town the marriage contract was sealed" (in villa ac non in oppido tabulae nuptiales sint consignatae, Apol.67). The parallel to Venus's complaint is striking: impares...nuptiae et praeterea in villa sine testibus. And assuming that his accusers did level such criticisms, this again suggests that not everyone had the same views as the jurists about what constituted a marriage.

In his defense, Apuleius refutes both charges. He shows that he has not gained financially from marrying Pudentilla, and that no provision in Roman law requires a public wedding. This second refutation is done with Apuleian bravura: after pointing out their rationale (a country wedding saved the expense of entertaining the townspeople), the sophist says, "I am amazed, nonetheless, that you balk so much at this country house of yours, when it is you who spends so much time in the countryside. That lex Iulia de maritandis ordinibus nowhere in its provisions forbids one to this extent: 'Let no man marry in a country house"' (miror tamen, quod tu a villa tantopere abhorreas, qui plerumque rure versere. lex quidem Iulia de maritandis ordinibus nusquam sui ad hunc modum interdicit: 'uxorem in villa ne ducito,' 88 ). The infamous lex Iulia, which by Apuleius's time had come to affect the lives of the many provincials who had acquired Roman citizenship, does not go so far as to prohibit a quiet country wedding. The parody of legal language is effective,

${ }^{58}$ Cf. Dig. 20.1.4 = 22.4.4; also Cod. Iust. 5.4.9. On the role of tabulae in Roman legal transactions, see Meyer 91-124, with marriage tablets discussed on 117-18.

${ }^{59} \mathrm{On}$ the relative dating of the Apologia and the Metamorphoses see Harrison 2000: 9-10. The most compelling argument is that the Metamorphoses would have figured in the Apologia (along with the other works of Apuleius that are mentioned) if already written. Recent discussions of the Apologia, in addition to Harrison 2000: 39-88, include Hunink 1997 and 1998, Bradley 1997 and 2000c, and Sandy, esp. 131-48. 
more so than the sophistry that follows on the country wedding as a symbol of fecundity. Yet it makes a serious point too: Apuleius shows the proconsul before whom the case was tried that he has mastered Roman law more fully than his accusers. (Similarly, he claims that he commands Latin and Greek, while his opponents speak them badly or not at all, using Punic instead; that he knows Rome, her history, and her leading men, his opponents only life in rural Africa.)

Although the accusers did apparently invoke Roman marriage law, according to the Apologia it was a screen for more wicked motives. And while it was Pudentilla's young son who brought accusation against Apuleius, the real force behind the attack were two other men. One was Pudens's uncle, Pudentilla's brother-in-law, who was eager to keep her money in his family's hands, rather than let it go to Apuleius. The other was Herennius Rufinus, father of the woman who married Pudentilla's other son. After this marriage took place, Apuleius alleges, the seedy Rufinus immediately began scheming to take over part of Pudentilla's vast fortune through his new son-in-law. That is, when the widow died, her fortune would pass to her sons, making it that much easier for Rufinus to get his hands on it. But then Pudentilla's decision to marry Apuleius got in the way. While for a time Rufinus used his son-in-law to put pressure on Pudentilla, he and Apuleius soon made amends, and the son-in-law then died. Now trying to engage his daughter to Pudentilla's other son-perhaps in fact an example of the north African type of remarriage-he hoped to come into her fortune that way. But Apuleius still needed to be removed.

The country marriage of Pudentilla and Apuleius is not the only wedding described in the Apologia. We also learn of the union between Rufinus's daughter and Pudentilla's older son. In describing it, Apuleius himself dwells on its irregularities, showing us that two could play the game of challenging the legitimacy of a marriage (Apol.76). Here, too, there seems to be a connection between the defense speech and the novel. Rufinus's daughter, Apuleius claims, was circulated by her mother among prospective husbands-as if she were a prostitute- "to be tested out" (ad experiundum). She was even engaged to one, but "after his fill" (post satietatem), he let her go. Had she not finally married Pudentilla's older son, "she might still have stayed at home a widow, before she was married" (fortasse an adhuc vidua ante quam nupta domi sedisset). One who should be a virgin is in fact like a widow. Similar phrasing occurs in Apuleius's description of Psyche: while her sisters were betrothed and married (desponsae iam beatas nuptias adeptae), Psyche, "a husbandless virgin stayed at home and mourned her lonely solitude" (virgo vidua domi residens deflet 
desertam suam solitudinem, 4.32).$^{60}$ Both Psyche and Rufinus's daughter are at the age of marriage, yet both are still at home-an unusual situation in classical society. Yet the similarity throws into relief a contrast: Psyche's virginity is emphasized again and again in the story, whereas Rufinus's daughter was only a "virgin again after her recent rejection" (virgo rursus post recens repudium), that is, a virgin only in name. While virginity was not required for a bride as such, the insinuation here is that the young woman has violated the lex Iulia de adulteriis and should not be allowed to marry. ${ }^{61}$

But the bride's sham virginity did not, Apuleius claims, bother her new husband. In fact, the Apologia maintains, Rufinus is able to exploit his son-inlaw's love for his new wife: if he refused to listen, "the old hand gave the young lover a source of worry: he threatened to take his daughter away" (scrupulum amanti adulescentulo veterator, minatur se filiam abducturum, 77). He could do so, presumably, since his daughter was still in his power; he even perhaps could end the marriage, by withdrawing his consent to it (though the law on this point was changing around the time of the trial). ${ }^{62}$ When it came to Apuleius's own marriage, he, along with the brother of Pudentilla's first husband, would have had to rely on other tactics, such as allegations concerning a lack of witnesses at the country wedding. Like another angry in-law, Venus, they seized upon whatever complaints they could.

As elsewhere in the Metamorphoses, then, an Apuleian insertion seems to play on events of the author's life-or an earlier depiction of events in his

${ }^{60}$ Vidua here must be translated as "husbandless," but the word more commonly referred to a widow, since "spinsters" were so rare in classical societies. As Zimmerman, Panayotakis, et al. note ad loc., the resulting phrase "appears to be an oxymoron." I do not have room to discuss at length the sisters' marriages, but in their complaints about them (at Met. 5.9-10) they offer interesting material for the social historian. The one, for instance, laments that her husband is "older than my father," vivid evidence for a situation demographic study has shown to be quite possible in Italian and provincial society: see Saller 1994: 25-41, building on Saller 1987 and Shaw, as well as Bagnall and Frier 111-34. The other moans that she must nurse her ailing husband as if she were a medica, a "female doctor," a profession known from Italian and provincial inscriptions (CIL 2.497; 5.3461; 6.5861, 6851, 7581; 8711, 8926, 9614-17, 33812; 8.24679; 12.3343; $13.2019,4334$ ). Since these medicae are generally slaves or freedwomen (cf. Treggiari 1976: 86), Apuleius's passage suggests that a woman of status might disdain nursing her husband. Cf. Plin. Ep. 8.18, a letter Apuleius may be alluding to here.

${ }^{61}$ This law seems not to have been explicit on what right to prosecute a husband had if he came to suspect his wife guilty of premarital sex with another partner. See the discussion of Thomas.

${ }^{62}$ Shown by Paul Sent. 5.6.15 (Bene concordans matrimonium separari a patre divus Pius prohibuit). Antoninus's prohibition was apparently upheld by Marcus Aurelius ( $\mathrm{Cod}$. Iust. 5.17.5). See Corbett 239-40, Treggiari 1991: 459-61, Arjava 44-6. 
life. ${ }^{63}$ Venus's malevolence in the story casts more bad light on Apuleius's opponents. Psyche's early life provides a contrast to Herennius's daughter. Cupid and his wife's total vindication corresponds to the acquittal implied by publication of the Apologia. Would Apuleius expect readers of his Metamorphoses to make these connections? A sure answer is not possible here, but it is worth noting that, their differences notwithstanding, the Apologia shares important similarities with the Metamorphoses. Both are in Latin and draw on a range of Latin literature, while also looking to Greek models; both take place in a provincial setting; both revolve around magic; the Metamorphoses has splendid trial scenes in books 3 and 10 (neither of which is in the Greek epitome of the original Lucius story); Roman law plays a role in both. One would certainly expect the audience of the two works to be similar: well-educated individuals, pleased to compare their learning with that of Apuleius, or the proconsul Claudius Maximus, or his predecessor Lollianus Avitus. ${ }^{64}$ If publication of the Apologia helped make Apuleius famous, it is not surprising that he should allude to it in a later work, and that he might, in writing a novel, be inspired by the contents and style of the earlier speech.

Since the relationship between the two texts is ultimately, and in good Apuleian fashion, elusive, though, we might end on a different, social historical note. In Cupid and Psyche, and in the Apologia, what threatens the marriages depicted is not the law as such, but appeal to it by difficult family members. This fact is not surprising: it would have been those with an immediate interest in the situation who challenged apparently irregular arrangements. Their motives, Apuleius's writings suggest, might have to do with maintaining the family's status, or they might be concerned with the division of property. ${ }^{65}$ Personal jealousies no doubt played a role too.

The legal sources, the Digest above all, are of inestimable value for anyone trying to understand marriage in ancient Roman society. ${ }^{66}$ They delineate the law of marriage, which can seem so unusual to us, and, if in the abstract,

${ }^{63}$ The trial of book 3 parallels the Apologia in general; Met. 1.24-5 (on fish) seems to have some relation with Apol. 29-41.

${ }^{64}$ Bradley 1997: 215-16 rightly emphasizes how Apuleius connects himself to Claudius's "intellectual capacity"; the published Apologia, in turn, connects Apuleius to his readers' intellectual capacity.

${ }^{65}$ For an essay on conflict in the Roman family, see Dixon, with a discussion of the Apologia at 162-4.

${ }^{66}$ Two recent and interesting collections of legal material are Evans Grubbs 2002 and Frier and McGinn, the former in translation, the latter with the Latin originals of the relevant texts. 
they reveal problems that might occur in connection with it. ${ }^{67}$ They are, then, concerned with the ideal; deviations from it are just that. It takes other sources to show us different mentalities: epitaphs that celebrate long years of mutual satisfaction between all categories of people in a variety of relationships; or the writings of Apuleius, which give us insight into how and why marriages might be challenged. As Gordon Williams has urged, social historians must use their imaginations, along with such sources, to see the gap that separates the rigid prescriptions of a jurist from what the far messier, and far more human, reality must have been. ${ }^{6}$

\section{WORKS CITED}

Arjava, A. 1996. Women and Law in Late Antiquity. Oxford.

Anné, L. 1941. Les rites des fiançailles et-la donation pour cause de marriage sous le basempire. Louvain.

Astolfi, R. 1995. La lex Iulia et Papia. 3rd ed. Padova.

Bagnall, R. and Frier, B. 1994. The Demography of Roman Egypt. Cambridge.

Bellen, H. 1971. Studien zur Sklavenflucht im römischen Kaiserreich. Wisebaden.

Bradley, K. 1997. "Law, Magic, and Culture in the Apologia of Apuleius." Phoenix 51: 203-23.

.2000a. "Fictive Families: Family and Household in the Metamorphoses of Apuleius." Phoenix 54: 282-308.

.2000b. "Animalizing the Slave: the Truth of Fiction." JRS 90: 110-25.

2000c. "Romanitas and the Roman Family: The Evidence of Apuleius' Apology."

Canadian Journal of History 35: 215-39.

Bowersock, G. 1965. "Zur Geschichte des römischen Thessaliens." RhM 108: 277-89.

Callebat, L. 1964. "L'Archaïsme dans les Métamorphoses d'Apulée." REL 42: 346-61.

Charpin, F. 1978-91. Lucilius: Satires. 3 vols. Paris.

Corbier, M. 2005. "Family and Kinship in Roman Africa." In M. George, ed., The Roman Family in the Empire: Rome, Italy, and Beyond. Oxford. 255-85.

Corbett, P. 1930. The Roman Law of Marriage. Oxford.

Cotton, H. 1993. "The Guardianship of Jesus Son of Babatha: Roman and Local Law in the Province of Arabia." JRS 83: 94-108.

Courtney, E. 1980. A Commentary on the Satires of Juvenal. London.

${ }^{67}$ Rescripts, though, sometimes illustrate the problems real individuals faced. For an excellent use of them to illumine family conflict see Evans Grubbs 2005.

${ }^{68}$ For a short but wide-ranging discussion of this gap see Williams. I would like to thank Andrew Gregory for commenting on an early version of this paper; members of the Yale Classics Department for their many ideas on a later draft presented at a seminar in January 2005; and the journal's anonymous readers and editor for invaluable suggestions. I also am grateful to Gordon Williams, whose teaching and scholarship have brought to life for me distinctive customs of the Romans-as well as their humanity. 
Dixon, S. 1997. "Conflict in the Roman Family." In B. Rawson and P. Weaver, eds., The Roman Family in Italy: Status, Sentiment, Space. Oxford. 149-67.

Dowden, K. 1994. “The Roman Audience of the Golden Ass.” In J. Tatum, ed., The Search for the Ancient Novel. Baltimore. 419-34.

Elster, M. 1991. “Römisches Strafrecht in den Metamorphoses des Apuleius.” In H. Hoffman, ed., Groningen Colloquia on the Novel, iv. Groningen. 135-54.

Evans Grubbs, J. 1995. Law and Family in Late Antiquity: The Emperor Constantine's Marriage Legislation. Oxford.

.2002. Women and the Law in the Roman Empire: A Sourcebook on Marriage, Divorce, and Widowhood. London and New York.

2005. "Parent-Child Conflict in the Roman Family: The Evidence of the Code of Justinian." In M. George, ed., The Roman Family in the Empire: Rome, Italy, and Beyond. Oxford. 93-128.

Fantham, E. 1995. “Aemilia Pudentilla: Or the Wealthy Widow's Choice.” In B. Levick and R. Hawley, eds., Women in Antiquity: New Assessments. London. 221-32.

Finkelpearl, E. 1998. Metamorphosis of Language in Apuleius: A Study of Allusion in the Novel. Ann Arbor.

Frier, B. and McGinn, T. 2004. A Casebook on Roman Family Law. New York.

George, M. 2005. The Roman Family in the Empire: Rome, Italy, and Beyond. Oxford.

Graverini, L. 2002. "Corinth, Rome, and Africa: A Cultural Background for the Tale of the Ass." In M. Paschalis and S. Frangoulidis, eds., Space in the Ancient Novel, Ancient Narrative Supplementum 1. Groningen. 58-77.

Harrison, S. 2000. Apuleius: A Latin Sophist. Oxford.

. 2002. "Literary Topography in Apuleius' Metamorphoses." In M. Paschalis and S. Frangoulidis, eds., Space in the Ancient Novel, Ancient Narrative Supplementum 1. Groningen. 40-57.

Honoré, T. 1994. Emperors and Lawyers 2nd ed. Oxford.

Hopkins, K. 1993. “Novel Evidence for Roman Slavery." Past \& Present 138: 3-27.

Hunink, V. 1997. Apuleius of Madauros: Pro se de magia (apologia). 2 vols. Amsterdam. 1998. “The Enigmatic Lady Pudentilla." AJP 119: 275-91.

Kenney, E. 1990. Apuleius: Cupid and Psyche. Cambridge.

Keulen, W. 1997. “Some Legal Themes in Apuleian Context." In Der antike Roman und seine mittelalterliche Rezeption. Basel. 203-29.

Laird, A. 1993. "Fiction, Bewitchment, and Story Worlds: The Implications of Claims to Truth in Apuleius." In C. Gill and T. Wiseman, eds., Lies and Fiction in the Ancient World. Exeter. 147-74.

Lattimore, R. 1942. Themes in Greek and Latin Epitaphs. Urbana.

Maehler, H. 1981. “Lucius the Donkey and Roman Law." MPL 4: 161-77.

Marache, R. 1952. La critique littéraire de langue latine et le dévloppement du goût archaïsant au IIe siècle de notre ère. Rennes.

Mason, H. 1994. "Greek and Latin Versions of the Ass-story." ANRW 2.34.2: 16651707.

Mattiaci, S. 1986. "Apulei e i poeti latini arcaici." In Munus amicitiae: scritti in memoria di Alessandro Ronconi. Florence. Vol. 1. 159-200.

McGinn, T. 1998. Prostitution, Sexuality, and the Law in Ancient Rome. Oxford. 
Meyer, E. 2004. Legitimacy and Law in the Roman World: Tabulae in Roman Belief and Practice. Cambridge.

Millar, F. 1981. "The World of the Golden Ass." JRS 71: 63-75.

Moreschini, C. 1994. Il mito di Amore e Psiche in Apuleio: saggio, testo di Apuleio, traduzione e commento. Naples: M. d'Auria.

Norden, F. 1912. Apuleius von Madauros und das römische Privatsrecht. Leipzig.

$\rightarrow$ Papaioannou, S. 1998. "Charite's Rape, Psyche on the Rock and the Parallel Function of Marriage in Apuleius' Metamorphoses." Mnemosyne 51: 302-24.

Quartuccio, D. 1978. “Sull'origine dell'adfectio maritalis.” Labeo 24: 51-6.

Rawson, B. 1986. “Children in the Roman Familia." In B. Rawson, ed., The Family in Ancient Rome: New Perspectives. London and Sydney. 170-200.

1989. "Spurii and the Roman View of Illegitimacy." Antichthon 23: 10-41.

Rosati, G. 2003. “Quis ille? Identità e metamorfosi nel romanzo di Apuleio." In M. Citroni, ed., Memoria e identità: la cultura romana costruisce la sua imagine. Florence. 267-96.

Rosenmeyer, P. "Enacting the Law: Plautus' Use of the Divorce Formula on Stage." Phoenix 49: 201-17.

Saller, R. 1987. "Men's Age at Marriage and Its Consequences in the Roman Family." CP 82: 21-34.

. 1993. "The Social Dynamics of Consent to Marriage and Sexual Relations: The Evidence of Roman Comedy." In A. Laiou, ed., Consent and Coercion to Sex and Marriage in Ancient and Medieval Societies. Washington. 83-104.

. 1994. Patriarchy, Property, and Death in the Roman Family. Cambridge.

Sandy, G. 1997. The Greek World of Apuleius. Mnemosyne Supplement 174. Leiden.

Schwartz, S. 2003. "Rome in the Greek Novel? Images and Ideas of Empire in Chariton's Persia." Arethusa 36: 375-94.

Shaw, B. 1987. "The Age of Roman Girls at Marriage: Some Reconsiderations." JRS 77: 30-46.

Stephens, S. 1994. "Who Read the Ancient Novels?" In J. Tatum, ed., The Search for the Ancient Novel. Baltimore. 405-17.

Summers, R. 1970. “Roman Justice and Apuleius' Metamorphoses." TAPA 101: 511-31. 1972. "Apuleius' juridicus." Historia 21: 120-6.

1973. "A Note on the Date of the Golden Ass." AJP 94: 375-83.

Talbert, R. 1984. The Senate of Imperial Rome. Princeton.

Thomas, J. A. C. 1961. “Accusatio adulterii.” Iura 12: 65-80.

Treggiari, S. 1976. “Jobs for Women." AJAH 1: 76-104. . 1991. Roman Marriage. Oxford.

Volterra, E. 1940. La conception du marriage d'après les juristes romains. Padua.

Watson, A., ed. 1985. The Digest of Justinian. Philadelphia.

Williams, G. 1996. "Representations of Women in Roman Literature." In D. Kleiner and S. Matheson, eds., I Claudia: Women in Ancient Rome. Austin. 126-38.

Winkler, J. 1985. Auctor \& Actor: A Narratological Reading of Apuleius' Golden Ass. Berkeley.

Zimmerman, M., Panayotakis, S., et al. 2004. Apuleius Madaurensis: Metamorphoses Books IV 28-35, V and VI 1-24: The Tale of Cupid and Psyche. Groningen Commentaries on Apuleius. Groningen. 